\title{
土木学会論文報告集
}

第 273 号・1978 年 5 月

\section{マグニチュード理論による河道網の連結構造 に関する統計則と指標}

\author{
STATISTICAL LAWS AND INDICES OF TOPOLOGIC STRUCTURE \\ OF CHANNEL NETWORKS BY MEANS OF MAGNITUDE THEORY
}

\author{
岩 佐 義 朗*.小林 信 久** \\ By Yoshiaki IWASA and Nobuhisa KOBAYASHI
}

\section{1. 序論}

河川のもつさまざまの水理・水文的性格を解明するに あたり，その基盤となる流域の自然的形態をなんらかの 形で定量的に表現することはきわめて重要である. Horton $^{1)}$ が位数に基づく河道数則, 河道長則等の経験 的地形則を提唱して以来, この種の地形形態学的研究は 各方面で広く進められてきた. Horton の位数化の方法 ならびにそれを簡潔にした Strahler の位数理論（以下， Horton のものを含め位数理論 と略称する）において は, 低位数の河道が高位数の河道に合流しても位数は変 化しないので, 河川のもつ水理・水文的性格を解明する には十分でない。このため, 河道網の階層的構造を表現 する各種の河道分類法が， $\mathrm{Shreve}^{2)}$ らによって提案さ れた.

本論文は，流域の幾何学的特性ならびに構造と密接な 関係をもつ河道網のトポロジー特性を対象としてその確 率統計的性格を明らかにしようとしたものである.ま ず, 従来の研究をまとめ, 問題点を列挙するとともに, その発展を図る本研究の意義を明確にする.ついで, 河 道網の連結構造をより詳しく把握, 表現するため, 位数 理論に代り, Shreve ${ }^{2)}$ の提唱したマグニチュード理論 および Jarvis ${ }^{3)}$ の高さ (height) の概念を用い，河道網 の階層的構造を表現して，その一般的なトポロジー特性 を表わす統計則を理論的に求めた. また，各河道網個有 のトポロジー特性を定量的に比較するため, 著者らは 3 種の指標を新たに提案して，これらの指標の值を検討す ることにより, 従来の分岐比の比較より詳しい情報が得 られることを実証している.さらに，現在広く用いられ ている位数理論の欠点を補うため, マグニチュード理

$*$ 正会員 工博 京都大学教授 工学部土木工学科

** 学生会員 工修 京都大学大学院博士課程

(フメリカ合衆国マサチューセッツ工科大学大学院留学中)
論と位数理論との関係を明らかにして，その関係より得 られる河道リンク位数をも提唱しょうとしたものであ る.

\section{2. 従来の研究}

Horton の提案した河道網に関する位数化の方法は複 雑なうえに, 主観的な判断も入るので, Strahler はそ の方法を簡潔にした. 現在では, Strahler 位数理論の 方が広く用いられており, Strahler 位数のことを単に 位数とよんでいる. 位数理論においては, ソース数 $n$, 最大位数 $k$ の河道網に打ける位数 $u$ の河道数を $N_{u}$ で 表わすと, 河道数則 ${ }^{1}$ は次のように表わされる.

$$
N_{u}=R_{b}{ }^{k-u}
$$

ここに, $R_{b}$ は分岐比とよばれる定数である. 実測值 の河道数 $N_{u}$ より分岐比 $R_{b}$ を決定する方法には, 種 々のものが提案されている4). 各位数 $u$ に対する分岐比 $B_{u}=N_{u-1} / N_{u}$ の幾何平均として求めると, 次のように なる。

$$
R_{b}=\left\{\prod_{u=2}^{k}\left(N_{u-1} / N_{u}\right)\right\}^{\frac{1}{k-1}}=n^{\frac{1}{k-1}}
$$

また, 算術平均 $\bar{B}_{u}$ は次式で与えられる.

$$
\bar{B}_{u}=\sum_{u=2}^{k}\left(N_{u-1} / N_{u}\right) /(k-1)
$$

一方, 実測值 $N_{u}$ に対する回帰分析より得られる分岐 比 $R_{b}{ }^{\prime}$ は，次のように表わされる.

$$
\log R_{b}{ }^{\prime}=6 \sum_{u=1}^{k-1}(k+1-2 u) \log N_{u} / k(k+1)(k-1)
$$

Shreve ${ }^{2)}$ および高棹 ${ }^{5)}$ は，「地質的影響が強く作用し ない場合には，自然の河道網はトポロジー的ランダムで ある」という仮定 (I) を用い，自然の河道網は統計的 に河道数則に従うことを理論的に証明した.ソース数 $n$ の河道網の $n$ 個の位数 1 の河道が互いに区別がある場合 のトポロジー的に異なった河道配列の総数 $Y_{n}$ は次式で 
与えられる

$$
Y_{n}={ }_{2 n-2} P_{n-1}
$$

ところが, $n$ 個の位数 1 の河道は互いに区別がないから， トポロジー的に異なる河道網 (topologically distinct channel networks ${ }^{2)}$, TDCN) の総数 $Z_{n}$ は次のように 表わされる5).

$$
Z_{n}=Y_{n} / n !={ }_{2 n-1} C_{n-1} / n
$$

ソース数 $n$ のトポロジー的に異なる河道網の出現する確 率は，ランダム性の仮定（I）よりすべて等しく，1/ $Z_{n}$ である. また, 高棹 ${ }^{5)}$ は, ソース数がきわめて大きい河 道網の河道配列に関する $1 / 4$ 則, $1 / 2$ 則等を統計的に求 めているが，これらの統計則は河道網の一般的トポロジ 一特性を表わすものとして意義があるが，各河道網個有 のトポロジー特性を表現するには十分でない.

Strahler の提案した位数化の方法では, 位数 $u$ の河 道と位数 $u-1$ 以下の河道との合流が，位数化に際し無 視されている.ところが, 合流点では, 河川形態的なら びに水理・水文的な特性は変化する. また, 河道の合流 に対して代数的結合則が成立しないため，同じ位数の河 道でもその河道長, 集水面積等に非常なばらつきが生じ ることがある. Shreve ${ }^{2)}$ はこれらの欠点を改良するた め, 河道網構成最小単位であるリンク，つまり隣接する 2 つの節点を結ぶ河道部分を対象とし, 各リンクに対し てそれより上流にあるソース数と定義されるマグニチュ ードによって河道を分類する方法, マグニチュード理論 を提案した.ここに，節点とは，河道最上流端であるy 一ス，合流点および対象河道網最下流端つまりシンクを あわせたものであり，河道網において点を構成するもの の集合である.マグニチュードの定義より，外部リンク， すなわち位数 1 の河道のマグニチュードは 1 であり, マ グニチュード $i_{1}$ と $i_{2}$ の 2 つのリンクが合流してでき るリンクのマグニチュードは $i_{1}+i_{2}$ となる. また， 、 グニチュード 2 以上のリンクをまとめて, 内部リンクと よばれる.なお，位数によって河道を分割した場合の河 道部分は，セグメント（segment）とよばれ，連続する 1 つ以上のリンクからなる.

Shreve より前に, Scheidegger ${ }^{6)}$ は consistent order による河道分類法を提案しているが, consistent order とマグニチュードの間には 1 対 1 の関係が成立する.つ まり, マグニチュード $i$ のリンの consistent order $u_{c}$ は次の式で与えられる.

$$
u_{c}=\log _{2}(2 i)
$$

したがって，これらの概念は同一とみなすことができる が, マグニチュードの方はトポロジー的に明確な意味を もち，また，取り扱いが簡単であるので，以下では， 、 グニチュード理論のみを取り扱うことにする.

Stall $\cdot \mathrm{Fok}^{7)}$ は，位数が整数值しか取り得ないことに
よって生じる先述の欠点を補うため, 比例河道位数 (proportional stream order) $u_{p}$ を提案し, $u_{p}$ を次の ように提案した.

$$
\begin{aligned}
& u_{p}=u+u_{x} \cdots \cdots \cdots \\
& u_{x}=\left(i-i_{1}\right) /\left(i_{2}-i_{1}\right)
\end{aligned}
$$

ここに, $u$ は, 対象とするマグニチュード $i$ のリンク を含む セグメントの位数, $i_{1}$ はこのセグメント最上流 端リンクのマグニチュード，そして $i_{2}$ はこのセグメン ト最下流端 リンクのマグニチュードである. ただし, $i_{2}=i_{1}$ のときは $u_{x}=0, i=i_{2}$ の ときは $u_{x}=0.99$ とす る. しかし, この方法では, $u_{x}$ を一種の比例配分によ って与えているのでその理論的根拠がない.

一方, Woldenberg ${ }^{8)}$ は水系を開いたシステムと考え, そのシステムに対する対比成長 (allometric growth) モ デルにより流域の平衡状態においては, 流域の地形量お よび水理量は互いにべき乗の関数関係があることを示 し，位数に対し次式で定義される 絶対河道位数 (absolute stream order) が存在するとしている.

$$
U_{a}=R_{b}{ }^{u-1} \text {. }
$$

ここに, $R_{b}$ は分岐比である.

$\mathrm{Jarvis}^{3)}$ は, 節点に関して高さという新しい概念を提 案した. 節点高さはその節点に対するパス，すなわち節 点よりシンクへ至る一連のつながりのなかに含まれるリ ンク数と定義される. したがって,ソース高さは,ソース よりシンクへ至る外部パスに含まれるリンク数を,また， 合流点高さは, 合流点よりシンクへ至る内部パスに含ま れるリンク数を表わすことになる. Werner·Smart ${ }^{9)}$ は， 節点高さ, ソース高さ, 合流点高さをそれぞれ, パス長 (path length), 外部パス長, 内部パス長と名づけたが, パスに沿う実際の河道長と混同しやすいので, 本論文で は高さと称す．高さの概念から得られる河道網のトポロ ジー特性を表わ寸重要な指標としては, 対象河道網に含

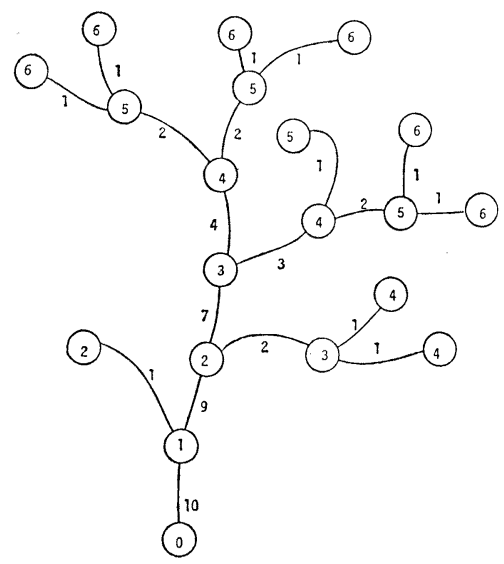

Fig. 1 A channel network with 10 sources. Numbers indicate the link magnitudes and the node heights. 
まれるすべてのソースの高さの最大值である最大ソース 高さ (maximum source height), およびこれらのソー スの高さの算術平均である平均ソース高さ (mean source height) が提案されている. Shreve ${ }^{10)} ら$ らはポロ ジー的ランダム性の仮定 (I) を用い, ソース数 $n$ の河 道網の最大ソース高さおよび平均ソース高さの期待值 を, 反復関係を利用し, 数值解析によって求めている.

Fig. 1 はソース数 10 の河道網の一例を示したもので ある. この河道網の最大ソース高さ, 平均ソース高さは それぞれ, 6 および 5.1 である.

グラフ理論を適用し, 河道網の幾何学的連結構造を表 現しようとする試みもなされている ${ }^{11}$.グラフ理論を適 用すれば, 河道網は有向グラフとみなすことができ, そ の連結構造はループを含まないトリーとなる. 以下に, 本研究でおもに用いるマグニチュードおよび高さによっ て河道網の連結構造が簡潔に表現されることを示そう.

いま, ソース数 $n$ の河道網において, 有向枝（リン ク）の向きを流れの流下方向にとり, 節点および有向枝 の番号を決定する際, 節点とその節点から出る有向枝の 番号が対応するように決めるものとする. また，シンク より各節点に向から仮想の有向枝をトリーに加えると, この仮想の有向枝によって成る部分グラフは, もとのト リーの補木となる.トリーに関する有向接続行列 $A_{T}$ と 有向原始ループ行列 $B_{T}$ については,一般に次の関係が 成立することが証明される

$$
{ }^{t} B_{T}=A_{T}{ }^{-1}, B_{T}={ }^{t}\left(A_{T}{ }^{-1}\right)
$$

ここに, $A_{T}, B_{T}$ はともに $(2 n-1) \times(2 n-1)$ 正方行 列であり, また, $t$ は転置行列を表わしている. 河道網 を行列表示したとき, トポロジ一的に異なる河道網に対 しては，それを表示した行列が異なるようにすることが 必要である. そのためには, 節点番号を決定する際, シ ンクより出発し上流方向へ, 各合流点では左へ進み, ソ

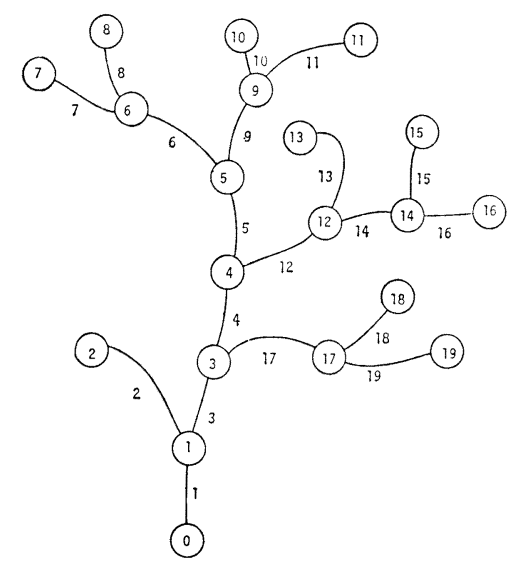

Fig. 2 A channel network with 10 sources. Numbers indicate the node numbers and the branch numbers.
Table 1

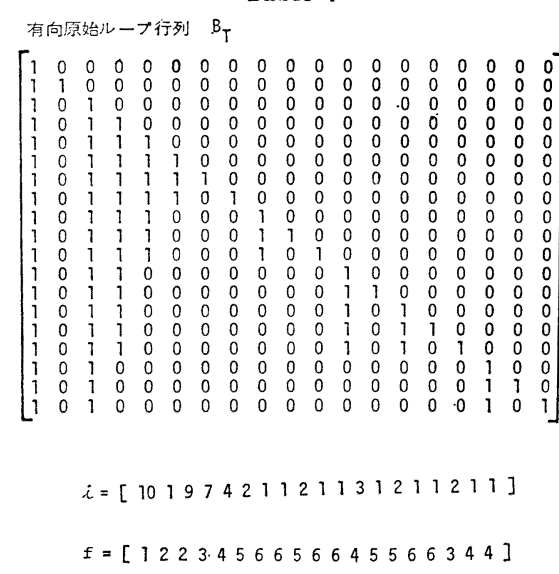

一スに達すれば向きを変え, 最終的にシンクへ戻ってく るように各節点に番号 $1,2, \cdots, n$ をつければよい.こ の方法で, Fig. 1 の河道網の各節点および有向枝に番 号をつけた例を Fig. 2 に示している.

次に, 行列 $B_{T}$ より,距離ベクトル $\boldsymbol{f}$ およびマグニチ ニードベクトル $\boldsymbol{i}$ を次のように定義することがきでる.

$$
\begin{aligned}
& \boldsymbol{f}=\boldsymbol{I} \cdot{ }^{t} B_{T} \cdots \cdots \cdot \\
& \boldsymbol{i}=\left(\boldsymbol{I} \cdot B_{T}+\boldsymbol{I}\right) / 2
\end{aligned}
$$

ここに，I はその成分がすべて 1 である行列ベクトルを 表わす. 距離ベクトル $\boldsymbol{f}$ の $j$ 番目の成分は節点番号 $j$ の節点高さを, そしてマグニチュードベクトル $i$ の $j$ 番目の成分は枝番号 $j$ の枝 (リンク) のマグニチュー ドを表わす. Fig. 2 に示した河道網に対する有向原始 ループ行列 $B_{T}$, 距離ベクトル $\boldsymbol{f}$ おびマグニチュード ベクトル $i$ を Table 1 に示している.

\section{3. マグニチュード理論と位数理論との関係}

\section{（1）河道リンク位数}

まず,マグニチュード理論と位数理論との関係を, ラ ンダム性の仮定（I）を用い, 統計的に求めよう.

マグニチュード $i$ のリンクより上流には $i$ 個のソー スが存在するから，このリンクより上流の小河道網に 対する TDCN の総数は, 式 (6) より $Z_{i}$ である. そ の中で, マグニチュード $i$ のリンクの位数が $u$ である $\mathrm{TDCN}$ の数を $\left(Z_{i}\right)_{u}$ で表わすと, 高棹 ${ }^{13)}$ によって 導 かれたのと同じ反復関係を与える式が成立する ${ }^{14)}$.

$$
\left.\begin{array}{rl}
\left(Z_{i}\right)_{u}=2^{i-2} & (u=2) \\
=\sum_{j=2^{u-2}}^{[i / 2]} 2^{i-2 j} \cdot{ }_{i-2} C_{i-2} \cdot\left(Z_{j}\right)_{u-1} \\
\left(3 \leqq u \leqq\left[\log _{2} 2 i\right]\right.
\end{array}\right\}
$$

ここに， [ は ガウス記号を表わす. $u=3$ の場合, $\left(Z_{j}\right)_{2}=2^{j-2}$ を式 (14) に代入して計算すれば, 


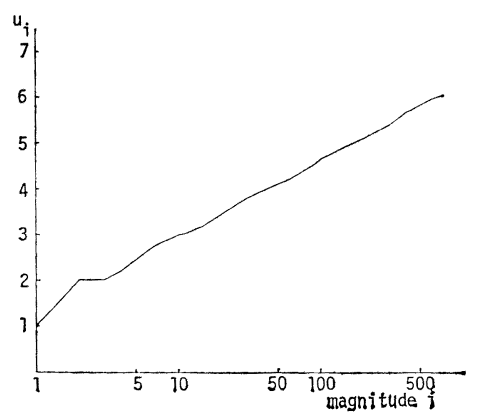

Fig. 3 Expected Strahler stream order of a link of magnitude $i$ versus magnitude $i$.

$$
\left(Z_{i}\right)_{3}=\frac{1}{4}\left\{(2+\sqrt{2})^{i-2}+(2-\sqrt{2})^{i-2}\right\}-2^{i-3}
$$

となる. 式 (15) を式 (14) に代入して計算すれば, $\left(Z_{i}\right)_{4}$ が求まり, 以下順次 $\left(Z_{i}\right)_{u}$ を求めることができ る. マグニチュードiのリンクの位数の期待值を $u_{i}$ で 表わすと, ランダム性の仮定より, $u_{i}$ は次のように表 わされる.

$$
u_{i}=\sum_{u=2}^{\left[\log _{2} 2 i\right]} u \cdot\left(Z_{i}\right)_{u} / Z_{i}
$$

Fig. 3 には, マグニチュード $i$ と位数の期待值 $u_{i}$ と の関係が示されているが, $u_{i}$ と $i$ の間には, 次の関係 が近似的に成り立つことがわかる。

$$
u_{i}=\alpha+\beta \log i
$$

ここに, $\alpha, \beta$ は定数である.

式（17）で表わされるマグニチュードと位数との近似 的関係を用い, 位数 $u$ の河道セグメントに含まれるマグ ニチュードiのリンクの河道リンク位数 (stream link order） $u_{l}$ を次のように定義する.

$$
\begin{aligned}
& u_{l}=u-u_{y} \cdots \ldots \ldots \ldots \ldots \ldots . . . . . \\
& u_{y}=\log \left(i / i_{d}\right) / \log \left(i_{0} / i_{d}\right)
\end{aligned}
$$

ここに， $i_{d}$ は対象とするマグニチュード $i$ のリンクを 含む位数 $u$ のセグメント最下流端リンクのマグニチュ 一ド, $i_{0}$ はこのセグメント上流端で 合流する 2 つ位 数 $(u-1)$ セグメントの最下流端リンクのマグニチュー ドの平均值である.ただし, 式 (17) の $u_{i}$ の值を, $i$, $i_{d}, i_{0}$ のそれぞれに対して $u_{l}, u, u-1$ としている.ここ で, 河道リンク位数と名づけたのは, 各リンクに対して 実数域にまで拡張された位数が定義されるからである.

次に, 式（18）および（19）で定義された河道リンク 位数に対しても位数理論の地形則と同じ地形則が成立す ることを証明しょう. 流域内のある地点あるいはそれよ り上流の小流域全体に対して定義される地形量 $V$ は, その地点のマグニチュード $i$ の関数として, 一般的に ほぼ次のように表わされる ${ }^{15)}$.

$\log V_{i}=a+b \log i$
ここに, $a, b$ は定数である. この地形量 $V$ の位数に対 する地形則は，一般的に次のように表わされる.

$$
V_{u}=V_{1} R_{v}{ }^{u-1}
$$

ここに, $V_{1}, R_{v}$ は定数である. いま, マグニチュード $i$ のリンクの河道リンク位数を $u_{l}$ とすると, 次の関係 が常に成り立つ.

$$
V_{i}=V_{u_{l}}
$$

さらに， $i_{0}$ および $i_{d}$ の定義より，マグニチュード $i_{0}$, $i_{d}$ のリンクはそれぞれ位数 $u-1, u$ のセグメント最下 流端リンクであるので, 次の関係が成立する.

$$
V_{i_{0}}=V_{u-1}, V_{i_{d}}=V_{u}
$$

ところが,マグニチュードに対する地形則として式 (20) が成立するならば， $V_{i_{0}}, V_{i_{d}}$ はそれぞれ次式で与えら れる。

$$
\left.\begin{array}{l}
\log V_{i_{0}}=a+b \log i_{0}, \\
\log V_{i_{d}}=a+b \log i_{d}
\end{array}\right\}
$$

また, $V_{u-1}, V_{u}$ は位数理論の地形則 (21) が成り立つ ならば，それぞれ次のように表わされる。

$$
\left.\begin{array}{l}
\log V_{u-1}=\log V_{1}+(u-2) \log R_{v} \\
\log V_{u}=\log V_{1}+(u-1) \log R_{v}
\end{array}\right\}
$$

式 (23)〜 (25) より， $a, b$ はそれぞれ次のように与え られる。

$$
\begin{aligned}
& a=\log V_{1}+\left\{(u-1)+\log i_{d} / \log \left(i_{0} / i_{d}\right)\right\} \log R_{v} \\
& b=-\log R_{v} / \log \left(i_{0} / i_{d}\right)
\end{aligned}
$$

式 (26) および (27) を式 (20) に代入して, 式 (19) で 定義される $u_{y}$ を用いると， $V_{i}$ は次のようになる.

$\log V_{i}=\log V_{1}+\left(u-u_{y}-1\right) \log R_{v}$

式 (18) および (22) を式 (28) に代入すれば,

$$
V_{u l}=V_{1} R_{v}^{u_{l}-1}
$$

となり, 河道リンク位数 $u_{l}$ に対しても位数理論の地形 則と同じ地形則が成立することがわかる.

\section{(2) ソース数則}

ソース数 $n$, 最大位数 $k$ の河道網における位数 $u$ の 河道より上流の小流域に含まれるソース数の平均值を $\bar{i}_{u}$ で表わせば, 式 (17) で表わされるマグニチュード と位数の関係より, $\bar{i}_{u}$ に対しても河道数則と同様のソ 一ス数則が成立すると仮定される. すなわち,

$$
\begin{aligned}
& \bar{i}_{u}=R_{m}{ }^{u-1} \ldots \ldots \ldots \ldots \ldots \ldots \ldots \ldots \ldots \\
& R_{m} \simeq \bar{i}_{u} / \bar{i}_{u-1}(u=2,3, \cdots, k)
\end{aligned}
$$

ここに, 定数 $R_{m}$ をソース数比と名づけることにする. 実測值の $\bar{i}_{u}$ から $R_{m}$ を求める場合, 各位数 $u$ に対す るソース数比 $\bar{i}_{u} / \bar{i}_{u-1}$ の幾何平均をソース数比 $R_{m}$ と すると, $R_{m}$ は次のように表わされる.

$$
R_{m}=\left\{\prod_{u=2}^{k}\left(\bar{i}_{u} / \bar{i}_{u-1}\right)\right\} \frac{1}{k-1}=n \frac{1}{k-1}
$$


Table 2 Bifurcation Ratios

\begin{tabular}{|c|ccccc|}
\hline River & $n$ & $k$ & $R_{b}$ & $\bar{B}_{u}$ & $R_{b}^{\prime}$ \\
Shingu & 607 & 6 & 3.60 & 3.75 & 3.73 \\
Tozu & 251 & 5 & 3.98 & 4.01 & 3.92 \\
Kitayama & 243 & 5 & 3.95 & 4.25 & 4.18 \\
Kizu & 369 & 6 & 3.26 & 3.40 & 3.33 \\
Katșura & 293 & 5 & 4.14 & 4.14 & 4.12 \\
0i & 223 & 5 & 3.86 & 4.13 & 4.06 \\
Iti & 111 & 5 & 3.25 & 3.39 & 3.29 \\
Ado & 95 & 5 & 3.12 & 3.33 & 3.11 \\
Yasu & 71 & 4 & 4.14 & 4.28 & 4.27 \\
Echi & 38 & 4 & 3.36 & 3.59 & 3.24 \\
\hline
\end{tabular}

ただし， $\overline{i_{1}}=1$ かつ $\overline{i_{k}}=n$ である. 式 (2) および (31)

よりソース数比 $R_{m}$ と分岐比 $R_{b}$ とは等しい.

$$
R_{m}=R_{b}
$$

式（32）を式（30）に代入して,

$$
\overline{i_{u}}=R_{b}{ }^{u-1}
$$

式（10）および (33) より, マグニチュードは絶対河道 位数にほぼ等しいことがわかる. 対比成長モデルによる と, ある地形量 $V_{i}$ はマグニチュード $i$ の関数として 式 (20) で与えられることになり, マグニチュード理論 の地形則の一般的関数形 (20) と一致する. しかし, 個 々の地形量とマグニチュードとの関係は, 厳密には式 (20) によって与えられないので, 詳しくかつその物理 的意味を明確にして説明するには, 対比成長モデルでは 不十分である.

Table 2 には，10 河川において測定したソース数 $n$, 最大位数 $k$ および分岐比 $R_{b}, \bar{B}_{u}, R_{b}{ }^{\prime}$ が示されている. $R_{b}, \bar{B}_{u}, R_{b}{ }^{\prime}$ はそれぞれ式 (2)〜 (4) で計算される. 測 定には, 国土地理院発行の縮尺 5 万分の 1 の地形図を用 い, 河道およびソースの位置は地形図上の青線最上流端 とした. どの河川に対しても分岐比 $R_{b}$ の值は, $\bar{B}_{u}$, $R_{b}{ }^{\prime}$ の值とほぼ等しく, ソース数 $n$ と最大位数 $k$ によ っておおよそ与えられることがわかる.

Table 3 には, 各河川に対する $\bar{i}_{u}$ の実測值と, 式 (33) で与えられる 理論值との比較が 示されている. 愛 知川以外の 9 河川では, $\bar{i}_{2}$ の 理論值は実測值に比べて 少し大きいが, 式 (33) で表わされるソース数則はほぼ

Table 3 Observed and calculated values of mean total number of sources per subnetwork of order $u ; \bar{i}_{u}$

\begin{tabular}{|l|lccccc|}
\hline River & & $\overline{i_{2}}$ & $\overline{i_{3}}$ & $\overline{i_{4}}$ & $\overline{i_{5}}$ & $\overline{i_{6}}$ \\
\hline Shingu & Obs. & 3.16 & 13.7 & 41.6 & 247 & 607 \\
Kitayama & Calc. & 3.60 & 13.0 & 46.8 & 168 & 607 \\
& Obs. & 3.18 & 14.0 & 58.5 & 243 & \\
Tozu & Calc. & 3.95 & 15.6 & 61.5 & 243 & \\
& Obs. & 3.24 & 13.2 & 38.3 & 251 & \\
0i & Calc. & 3.98 & 15.8 & 63.0 & 251 & \\
& Obs. & 2.94 & 9.73 & 64.5 & 223 & \\
Ibi & Calc. & 3.86 & 14.9 & 57.7 & 223 & \\
& Obs. & 3.00 & 11.0 & 32.0 & 111 & \\
Ado & Calc. & 3.25 & 10.5 & 34.2 & 111 & \\
Kizu & Obs. & 3.00 & 14.8 & 43.0 & 95 & \\
Katsura & Calc. & 3.12 & 9.75 & 30.4 & 95 & \\
Echi & Obs. & 2.90 & 12.1 & 39.5 & 145 & 369 \\
& Calc. & 3.26 & 10.6 & 34.7 & 113 & 369 \\
& Obs. & 3.14 & 12.5 & 62.3 & 293 & \\
Yasu & Calc. & 4.14 & 17.1 & 70.8 & 293 & \\
& Obs. & 4.71 & 8.67 & 38.0 & & \\
& Calc. & 3.36 & 11.3 & 38.0 & & \\
& Obs. & 2.53 & 16.0 & 71.0 & & \\
\hline
\end{tabular}

成り立つものと考えられる.しかし，河道数則およびソ 一ス数則がともに完全に成立する河道網においては，位 数 $u$ の河道には位数 $u-1$ の河道のみが流入すること になり, ある程度ソース数の大きい自然の河道網では, 位数 $1,2, \cdots, u-2$ の河道も位数 $u$ の河道に流入する ので, 河道数則およびソース数則を完全に満足する河道 網は，確率的にありえないといえよう。

次に, ソース数 $n$, 最大位数 $k$ の河道網における グニチュード $i$ のリンクの河道リンク位数の平均值 $\bar{u}_{l}$ は， $i_{0}$ および $i_{d}$ に対して式 (33) で表わされる関係が 成立すると, $i_{d}=R_{b}^{u-1}$ かつ $i_{0}=R_{b}{ }^{u-2}$ となり，これら の式を式 (18) および（19）に代入して，次のように表 わすことができる.

$$
\bar{u}_{l}=1+\log i / \log R_{b}
$$

したがって，あるリンクのマグニチュードがわかれば, 上式よりそのリンクの河道リンク位数のおおよその值を 知ることができ，そのリンクに対する地形量は式 (29) より求められることになる.

Fig. 4 はマグニチュードと河道リンク位数および比 例河道位数の平均值 $\bar{u}_{l}, \bar{u}_{p}$ の関係を示したものである. 河道リンク位数は, マグニチュードと位数との理論的近 似式（17）に基づいて定義されているので, 実測值と理 論值との適合性がよい. 式（8）および（9）で定義され る比例河道位数はもともと経験的に提案されたものであ るが, マグニチュード 3 以上のリンクの比例河道位数は 河道リンク位数の実測值とほぼ同様の変化をする.

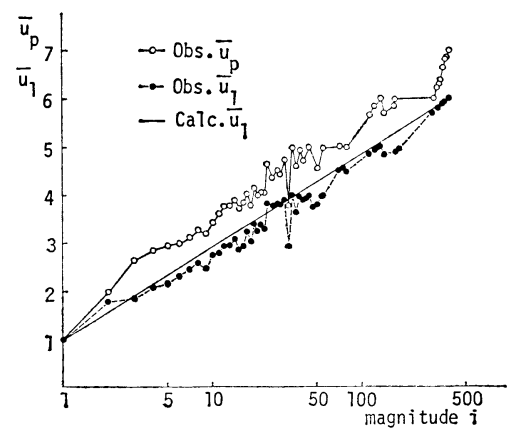

Fig. 4 Observed average proportional stream order $\bar{u}_{p}$, and observed and theoretical stream link order $\bar{u}_{l}$ versus magnitude $i$ for Kizu River.

\section{4. マグニチュード理論における河道配列の 統計則}

\section{（1）河道リンク数則}

マグニチュードと河道リンク数との関係を, トポロジ 一的ランダム性の仮定を用いて, 統計的に求めることに 
する.

ソース数 $n$ の河道網におけるマグニチュード $i(1 \leqq$ $i \leqq n)$ のリンク数を $M_{i}{ }^{n}$ で表わすと, 次の関係が常に 成り立つ.

$$
\sum_{i=1}^{n} M_{i}^{n}=2 n-1
$$

いま, ソース数 $n$ の河道網に対する $Z_{n}$ 個の TDCN の中で, マグニチュード $i$ のリンクを $j$ 本持つ TDCN の数を $\left(Z_{n}\right)_{i j}$ で表わすと, すべてのマグニチュードに 対して，次の式が成り立っ.

$$
\sum_{j=0}^{J}\left(Z_{n}\right)_{i j}=Z_{n} \quad(i=1,2, \cdots, n)
$$

ただし，J=[n/i]

次に, $j=J$ と $0 \leqq j \leqq J-1$ の 2 つの場合に分けて, $\left(Z_{n}\right)_{i j}$ を求める.

(i ） $j=J$ の場合 : マグニチュード $i$ のリンクの上 流には $i$ 本の外部リンクがある. いま, マグニチュー ド $i$ のリンク数は $j$ であるから, $i \cdot j$ 本の外部リンク がマグニチュード $i$ のリンクの上流域にあることにな る.したがって, 残りの外部リンク数は $n-i \cdot j$ である. ここに, マグニチュード $i$ のリンクの $j$ 本と外部リン $\eta n-i \cdot j$ 本の合計 $N=n-j(i-1)$ 本の リンクによる 配列の総数は, 式 (5) より $Y_{N}$ で表わされる. ところ が, マグニチニード $i$ のリンクおよび外部リンクは互 いに区別され得ない，また，マグニチュード $i$ のリンク より上流の小河道網に対する河道配列の仕方は $Z_{i}$ 通り である. したがって， $\left(Z_{n}\right)_{i j}$ は次のように表わすこと ができる.

$$
\left(Z_{n}\right)_{i j}=\left(Z_{i}\right)^{j} Y_{N} / j ! \cdot(n-i \cdot j) !=F_{n i}{ }^{j} \cdots
$$
ただし，

$$
F_{n i}{ }^{j}=\left(Z_{i}\right)^{j} Z_{N N} C_{j}, N=n-j(i-1)
$$

(ii） $0 \leqq j \leqq J-1$ の場合 : $j=J$ の場合とほぼ同様 であるが, この場合には $(n-i \cdot j)$ 本の外部リンクでマ グニチュード $i$ のリンクが形成され $, j=j+1, j+2$, $\cdots J$ となる場合を除く必要があるので, $\left(Z_{n}\right)_{i j}$ は次の ように表わされる.

$$
\left(Z_{n}\right)_{i j}=F_{n i}{ }^{j}-\sum_{l=j+1}^{j}{ }_{l} C_{j} \cdot\left(Z_{n}\right)_{i l}
$$

ここで, 式 (37) と式 (39) をまとめると, 次のように なる.

$$
\sum_{l=j}^{j}{ }_{l} C_{j}\left(Z_{n}\right)_{i l}=F_{n i}{ }^{j} \quad(j=0,1, \cdots, J) \cdots
$$

$n, i$ を固定して $\left(Z_{n}\right)_{i j}(j=0,1, \cdots, J)$ を末知数と 考えると, 式 (40) は $J+1$ 個の $\left(Z_{n}\right)_{i j}$ を末知数とす る連立方程式と考えることができる．この連立方程式を 解けば, $\left(Z_{n}\right)_{i j}$ 㳄次のうに表わされる.

$$
\left(Z_{n}\right)_{i j}=\sum_{k=j}^{J} F_{n i}{ }_{k}{ }_{k} C_{j}(-1)^{k-j}
$$

いま,ソース数 $n$ の河道網におけるマグニチュード $i$ のリンク数の期待值を $m_{i}{ }^{n}$ で表わすと, トポロジー的 ランダム性の仮定より， $m_{i}{ }^{n}$ は次のように表わされる.

$$
m_{i}{ }^{n}=\sum_{j=1}^{f} j \cdot\left(Z_{n}\right)_{i j} / Z_{n}
$$

式（40）において， $j=1$ とおき，式（42）を計算すれ ば,

$$
m_{i}{ }^{n}=(n-i+1) Z_{i} Z_{n-i+1} / Z_{n}
$$

となる. また，式（43）で表わされるこの関係，すなわ ちリンク数の期待值 $m_{i}{ }^{n}$ に対しても式 (35) が成立す ることが証明される ${ }^{15)}$.

$$
\sum_{i=1}^{n} m_{i}{ }^{n}=2 n-1 \cdots
$$

ここで, 式 (43) を河道リンク数則と名ゔけることにす る.

次に, ソース数 $n$ の河道網におけるマグニチュード $i$ のリンク数の標準偏差を $\sigma_{i}{ }^{n}$ で表わせば, $\sigma_{i}{ }^{n}$ は次のよ らに表わされる.

$$
\left(\sigma_{i}{ }^{n}\right)^{2}=\sum_{l=0}^{J}\left(l-m_{i}{ }^{n}\right)^{2}\left(Z_{n}\right)_{i l} / Z_{n}
$$

式（40）において， $j=2$ を代入した式を利用して, 式 （45）を計算すれば次のようになる.

$$
\left.\begin{array}{cc}
\left(\sigma_{i}{ }^{n}\right)^{2}=m_{i}{ }^{n}-\left(m_{i}{ }^{n}\right)^{2}+2\left(Z_{i}\right)^{2} Z_{n-2(i-1)} \\
\cdot_{n-2(i-1)} C_{2} / Z_{n} & (1 \leqq i \leqq n / 2) \\
=m_{i}{ }^{n}-\left(m_{i}{ }^{n}\right)^{2} & (n / 2<i \leqq n)
\end{array}\right\}
$$

ソース数 $n$ の河道網におけるマグニチュード $i$ の実 際のリンク数 $M_{i}{ }^{n}$ が次の範囲に入る確率は, Tschebycheff の公式より $3 / 4$ 以上である.

$$
m_{i}{ }^{n}-2{\sigma_{i}}^{n}<M_{i}{ }^{n}<m_{i}{ }^{n}+2 \sigma_{i}{ }^{n}
$$

河道リンク数の期待值 $m_{i}{ }^{n}$ およびその標準偏差 $\sigma_{i}{ }^{n}$ は，地質的影響が強く作用しない場合に対して，トポロ ジー的ランダム性の仮定（I）を用いて求められたもの であるから，いま対象としている河道網に対する地質的 影響の強弱を表わす地質制御指標 (geologic control index） $G$ を次のように定義することができる.

$$
G=\frac{1}{n} \sum_{i=1}^{n}\left|M_{i}{ }^{n}-m_{i}{ }^{n}\right| / \sigma_{i}{ }^{n}
$$

ソース数がほぼ同じ河道網に対しては，Gによって流 域の地質, 地形がその流域の河道網のトポロジー特性を 与える影響の大小, あるいは平均的な河道網からの偏差 を知ることができる．しかし，ソース数が非常に異なる 河道網に対しては, 式 (48) で定義された $G$ で十分で あるかどらか検討を要する.

次に, ソース数 $n$ が十分大きい場合, 式 (43) で与え られる期待值 $m_{i}{ }^{n}$ は次のように近似される.

(1) $1 \leqq i \leqq[3 n / 4]$ のとき, $m_{i}{ }^{n}$ は $i$ について単 調減少し, 


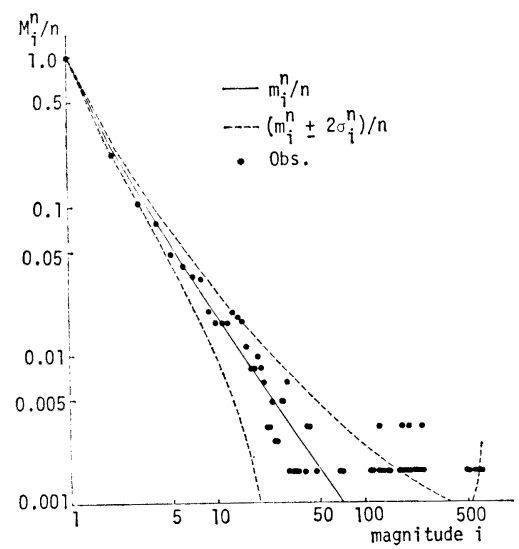

Fig. 5 Observed and calculated number of links $M_{i}{ }^{n} / n$ versus magnitude $i$ for Shingu River.

$$
m_{i}{ }^{n} \simeq n \cdot Z_{i} \cdot\left(\frac{1}{4}\right)^{i-1}
$$

(2) $[3 n / 4]<i \leqq n$ のとき, $m_{i}{ }^{n}$ は $i$ について単 調増加し,

$$
m_{i}^{n} \simeq_{2 n-2 i} C_{n-i}\left(\frac{1}{4}\right)^{n-i}
$$

式 (49) は, $i \geqq 3$ かつ $m_{i}{ }^{n} \geqq 1$ の範囲では, Stirling の公式を用いると, 次のように近似される.

$$
\log \left(m_{i}{ }^{n} / n\right) \simeq-\frac{3}{2} \log i-\frac{1}{4}
$$

したがって, この範囲においてのみ河道リンク数は式 （20）で表わされるような関数形で表現され, 対比成長 モデルは厳密には成立しないことが理解される。

Fig. 5 は新宮川のリンク数とマグニチュードの関係 である. 実測值は, $m_{i}{ }^{n} \pm 2 \sigma_{i}{ }^{n}$ の範囲にほぼ入ってお り, 新宮川に対しては, トポロジー的ランダム性の仮定 Table 4 Geologic control がおおよそ満足されているこ index

\begin{tabular}{|c|c|}
\hline River & $G$ \\
\hline Shingu & 0.723 \\
Tozu & 0.795 \\
Kitayama & 0.801 \\
Kizu & 0.750 \\
Katsura & 0.775 \\
$0 i$ & 1.036 \\
Ibi & 0.867 \\
Ado & 0.957 \\
Yasu & 0.966 \\
Echi & 0.957 \\
\hline
\end{tabular}

とがわかる. Table 4 には 10 河川に対する地質制御指標 $G$ の值が表示されている.ソー ス数が大きい河川ほど, Gの 值は小さくなる傾向がある が, 大井川に対する $G$ の值 は他の河川の值に比べて明ら かに大きい. このことは, 大井川では, 他の河川に比べ てその河道配列に及ぼす地質，地形的影響が大きいこと を示している. Table 2 の 分岐比の值を比較すれば, 大井川の分岐比の值は他の河川の值と変わらない. これ は, マグニチュード理論の河道リンク数則は, 河道網構 成最小単位であるリンクを対象とするので, 位数理論の 河道数則に比べて河道網のトポロジー特性をより詳しく 表現しているためと考えられる.

\section{（2）河道リンク分流・配分則}

ソース数 $n$ の河道網における河道リンクの合流に関し ては, マグニチュード $j$ と $i-j$ のリンクが合流して できるマグニチュード $i$ のリンク数の期待值を $m_{j i}{ }^{n}(j$ $=1,2, \cdots,[i / 2])$ とすると, 次のように表わされる.

$$
m_{j i}{ }^{n} / m_{i}{ }^{n}=\left(2-\delta_{j i / 2}\right) Z_{j} \cdot Z_{i-j} / Z_{i}
$$

ここに, $\delta_{j i / 2}$ はクロネッカーデルタである.

さらに,ソース数 $n$ の河道網における河道リンクの配 分に関しては, マグニチュード $i$ のリンクに合流する マグニチュード $j$ のリンク数の期待值を $\left(m_{j}{ }^{n}\right)_{i}(i=$ $j+1, j+2, \cdots, n)$ とすると, 次のように表わされる.

$$
\left(m_{j}{ }^{n}\right)_{i} / m_{j}{ }^{n}=2 \cdot Z_{i-j \cdot 2 n-2 i} C_{n-i / 2 n-2 j} C_{n-j}
$$

この式を河道リンク配分則と名づけることにする.

次に,河道リンク数則および河道リンク配分則より,高 棹が提案した $1 / 4$ 則， $1 / 2$ 則をより綮密に証明しよう.

ソース数 $n$ の河道網から外部リンクをすべて取り除い て構成される河道網の外部リンクにおいて, 取り除く前 のリンクを $k$ 個含む 外部リンク数の期待值を $\mathrm{NE}(k$ : n) で表わすと, 次の関係が成立する.

$$
\begin{aligned}
\mathrm{NE}(k: n) & =\left\{\sum_{i=k+3}^{n}\left(m_{k+1}{ }^{n}\right) i\right\} \frac{2^{k-1}}{Z_{k+1}} \\
& (1 \leqq k \leqq n-3) \quad \cdots \\
& =2^{n-2} / Z_{n} \quad(k=n-1) \cdots
\end{aligned}
$$

式 (54) は，河道リンク配分則 (53) より，

$$
\begin{array}{r}
\mathrm{NE}(k: n)=2^{k-1} \cdot \frac{m_{k+1}{ }^{n}}{Z_{k+1}}-2^{k} \frac{m_{k+2}{ }^{n}}{Z_{k+2}} \\
(1 \leqq k \leqq n-3) \quad \cdots \cdots
\end{array}
$$

となる.この式はさらに, 河道リンク数則 (43) より, 次のように表わされる.

$$
\begin{array}{r}
\mathrm{NE}(k: n)=2^{k-1} \cdot \frac{(n-k) Z_{n-k}}{Z n} \cdot \frac{n-k-2}{2 n-2 k-3} \\
(1 \leqq k \leqq n-3) \\
\cdots \cdots \cdots \cdots \cdots(57)
\end{array}
$$

また, ソース数 $n$ の河道網から外部リンクをすべて取り 除いて構成される河道網の外部リンク数の期待值は, 式 (55) および (56) より, 次のようになる.

$$
\sum_{k=1}^{n-3} \mathrm{NE}(k: n)+\mathrm{NE}(n-1: n)=m_{2}{ }^{n}
$$

外部リンクをすべて取り除いて構成される河道網の外部 リンクがもとの河道網の リンクを $k$ 個含む確率を $\mathrm{PE}$ (k:n) で表わすと，

$$
\mathrm{PE}(k: n)=\mathrm{NE}(k: n) / m_{2}{ }^{n}
$$

$1 \leqq k \leqq n-3$ の場合，式 (59) は式 (43) および (57) より,

$$
\mathrm{PE}(k: n)=2^{k-1} \cdot \frac{(n-k) Z_{n-k}}{(n-1) Z_{n-1}} \cdot \frac{n-k-2}{2 n-2 k-3}
$$


となり, $n$ および $n-k$ が十分大きいとき Stirling の 公式を用いて計算すれば，次のように近似される.

$$
\mathrm{PE}(k: n) \simeq\left(\frac{1}{2}\right)^{k}
$$

ソース数 $n$ の河道網から外部リンクをすべて取り除い て構成される河道網の内部リンクにおいて, 取り除く前 のリンクを $k$ 個含む内部リンク数の 期待值を $\mathrm{NI}(k$ : $n)$, その確率を $\mathrm{PI}(k: n)$ で表わすと, $\mathrm{NI}(k: n)$ は次 のように表わされる(5).

$$
\begin{aligned}
& \mathrm{NI}(k: n)=\frac{2^{k-1}}{Z_{n}}\left[\left\{(n-k) Z_{n-k-1}\right.\right. \\
& \left.\quad-2(n-k-1) Z_{n-k}\right\}+\{3 n-3 k-2) Z_{n-k} \\
& \left.\left.\quad-2(3 n-3 k-5) Z_{n-k-1}\right\}\right](1 \leqq k \leqq n-3)
\end{aligned}
$$

また, 内部リンクの総数の期待值は式 (62) より,

$$
\sum_{k=1}^{n-3} \mathrm{NI}(k: n)=m_{2}{ }^{n}-1
$$

となり, 確率 $\mathrm{PI}(k: n)$ は次のようである.

$$
\mathrm{PI}(k: n)=\mathrm{NI}(k: n) /\left(m_{2}{ }^{n}-1\right)
$$

この式は, $n$ および $n-k$ が十分大きいとき, Stirling の公式を用い，次のように近似される.

$$
\mathrm{PI}(k: n)=\left(\frac{1}{2}\right)^{k}
$$

いま, ソース数 $n$ の河道網から外部リンクを取り除い て構成される河道網のソース数が $j$ である TDCN の 数は $\left(Z_{n}\right)_{2 j}$ で与えられるから, 外部リンクを取り除い て構成される河道網のソース数が $j$ である確率 $P_{n}{ }^{j}$ は 次のようになる.

$$
P_{n}^{j}=\left(Z_{n}\right)_{2 j} / Z_{n}(j=1,2, \cdots,[n / 2])
$$

ところが, $\left(Z_{n}\right)_{2 j}$ は式 (41) より，

$$
\left(Z_{n}\right)_{2 j}=2^{n-2 j} \cdot{ }_{n-2} C_{n-j} \cdot Z_{j} \cdots
$$

また, ソース数 $j$ の期待值は式 (58) より $m_{2}{ }^{n}$ である から, 次の関係が成立する.

$$
\sum_{j=1}^{[n / 2]} j \cdot P_{n}^{j}=m_{2}^{n}=\frac{n(n-1)}{2(2 n-3)}
$$

以上の結果を用いて, ソース数 $n$ が十分大きい場合に 対して, $1 / 4$ 則および $1 / 2$ 則を証明しよう.まず，ソー ス数 $n$ の河道網における位数 $u$ の河道数の期待值を $N_{u}{ }^{n}$ で表わすと, $N_{2}{ }^{n}$ は式（68）より，

$$
N_{2}^{n}=\sum_{j=1}^{[n / 2]} j \cdot P_{n}^{j} \simeq \frac{1}{4} \cdot n
$$

ここで, $N_{u}{ }^{n}$ に対して一般的に次の関係が成立する.

$$
N_{u}{ }^{n}=\sum_{j=2^{u-2}}^{[n / 2]} N_{u-1}^{j} \cdot P_{n}^{j}
$$

式（69）および式（70）より，近似的に $1 / 4$ 則が成立す ることがわかる。

$$
N_{u}^{n} \simeq\left(\frac{1}{4}\right)^{u-1} \cdot n \quad\left(\frac{1}{4} \text { 則 }\right)
$$

次に, 位数 $u$ の河道が位数 $u-1$ の河道の合流点を $k$ 個持つ確率を ${ }_{k} P_{n}{ }^{u}$ で表わすと, 式 (61) より,

$$
{ }_{k} P_{n}^{2}=\mathrm{PE}(k: n) \simeq\left(\frac{1}{2}\right)^{k}
$$

となる. $u=3$ の場合, 次の関係が成立する.

$$
{ }_{k} P_{n}{ }^{3}=\sum_{j=k+1}^{[n / 2]} \mathrm{PE}(k: j) P_{n}^{j} \simeq\left(\frac{1}{2}\right)^{k}
$$

以下，同様に計算して，近似的に次の $1 / 2$ 則が成立する ことがわかる。

$$
{ }_{k} P_{n}{ }^{u} \simeq\left(\frac{1}{2}\right)^{k} \quad\left(\frac{1}{2} \text { 則 }\right)
$$

トポロジー的ランダム性の仮定 (I) より統計的に求 められたマグニチュード理論の河道リンク数則および河 道リンク配分則より, 同じ仮定 (I) より得られた位数 理論の $1 / 4$ 則, $1 / 2$ 則が誘導されることが証明された. このことより, マグニチュード理論における河道配列の 統計則の方が，位数理論の河道配列の統計則よりも，河 道網の一般的なトポロジー特性をより詳しく表現してい ることがわかる。

地形図上の河道網には, 実際の河道がすべて表わされ ていない. 式 (61)，(65）および（66）は，地形図より 得られた河道網のソース数, リンク長の分布等と実際の 河道網におけるこれらの值との関係を考えるとき有用と なる・

\section{（3） 河道リンク数と節点高さとの関係}

最後に, ソース数 $n$ の河道網における河道リンク数 $M_{i}{ }^{n}$ と節点高さとの関係を考えてみよう.この河道網の 節点高さ, ソース高さおよび合流点高さの総和をそれぞ れ $T_{n}{ }^{(N)}, T_{n}, T_{n}{ }^{(J)}$ で表わすと, 次の関係が常に成り 立つ.

$$
\begin{aligned}
& T_{n}{ }^{(N)}=\sum_{i=1}^{n}(2 i-1) M_{i}{ }^{n} . \\
& T_{n}=\sum_{i=1}^{n} i \cdot M_{i}{ }^{n} \ldots \ldots \ldots \ldots . . . . . . \\
& T_{n}{ }^{(J)}=\sum_{i=2}^{n}(i-1) M_{i}{ }^{n} .
\end{aligned}
$$

ここに, 式 (35) を用い, $T_{n}{ }^{(N)}, T_{n}{ }^{(J)}$ を $T_{n}$ で表わ せば, 次のようになる.

$$
\begin{aligned}
& T_{n}{ }^{(N)}=2 \cdot T_{n}-(2 n-1) \\
& T_{n}{ }^{(J)}=T_{n}-(2 n-1) \cdots
\end{aligned}
$$

したがって, $n, T_{n}$ が与えられると, 式 (78) および (79) より $T_{n}{ }^{(N)}, T_{n}{ }^{(J)}$ が決まることがわかる.

\section{5. 平均ソース高さと最大ソース高さ}

河道網のトポロジー特性指標として重要な平均ソース 高さと最大ソース高さを, ランダム性の仮定 (I) を用 い,ソース数 $n$ の関数として表わそう.

ソース数 $n$ の河道網において, 節点高さ $j$ の節点数 
を $f_{j}$, ソース高さ $j$ のソース数を $f_{j}{ }^{(s)}$, 合流点高さ $j$ の合流点数を $f_{j}(J)$ で表わすと, 次の関倸が常に成立す る.

$$
\left.\begin{array}{c}
\sum_{j=1}^{d} f_{j}=2 n-1 \\
f_{j}^{(s)}=f_{j}-\frac{1}{2} f_{j+1}, f_{j}^{(J)}=\frac{1}{2} f_{j+1} \\
(1 \leqq j \leqq d-1) \\
f_{d}^{(s)}=f_{d}, f_{d}^{(J)}=0 \quad(j=d)
\end{array}\right\}
$$

ここに, $f_{1}=1$ であり, $f_{j}(2 \leqq j \leqq d)$ は 2 以上の偶数 である.また, $d$ はこの河道網の最大ソース高さで, 次 の範囲の整数である.

$\log _{2} 2 n \leqq d \leqq n$

この河道網の 全節点高さ $T_{n}{ }^{(N)}$, 全ソース高さ $T_{n}$, 全 合流点高さ $T_{n}(J)$ は, 定義より次のように表わされる.

$$
\begin{aligned}
& T_{n}{ }^{(N)}=\sum_{j=1}^{d} j \cdot f_{j} \cdots \\
& T_{n}=\sum_{j=1}^{d} j \cdot f_{j}{ }^{(s)} \\
& T_{n}{ }^{(J)}=\sum_{j=1}^{d} j \cdot f_{j}(J)
\end{aligned}
$$

式 (80) および $(81)$ より, $T_{n}{ }^{(N)}$ および $T_{n}{ }^{(J)}$ は $T_{n}$ と $n$ で表わされ, 式 (78) および (79) と同じ結果を らる.したがって, 河道網のトポロジー特性を表わす指 標としては， $T_{n}$ あるいは平均ソース高さ $T_{n} / n$ ，また は最大ソース高さ $d$ を考えればよいことになる.

ランダム性の仮定（I）を用いれば，ソース数 $n$ の河 道網の全ソース高さの期待值 $t_{n}$ は, 式 (76) より次の ように表わされる。

$$
t_{n}=\sum_{i=1}^{n} i \cdot m_{i}{ }^{n}
$$

河道リンク数則（43）および式（44）を用いて計算する と, $Z_{n} t_{n}$ に関する次の反復関係が得られる.

$$
Z_{n} t_{n}=4 \cdot Z_{n-1} t_{n-1}
$$

ところが, $Z_{1} t_{1}=1$ であるから， $t_{n}$ は次のように表わさ れる.

$$
t_{n}=4^{n-1} / Z_{n}
$$

したがって, 平均ソース高さの期待值 $e_{n}$ は, 次式で与 えられる。

$$
e_{n}=4^{n-1} /\left(n \cdot Z_{n}\right)
$$

$n$ が大きい場合, 上式は Stirling の公式を用いて次の ように近似される.

$$
e_{n} \simeq 1.78 \sqrt{n-1}
$$

ソース数 $n$ の河道網の最大ソース高さの 期待値 $d_{n}$ を求めよう. そのため, ソース数 $n$, 最大ソース高さ $d$ の河道網の全ソース高さ $T_{n}$ の取り得る最小值および最 大值をそれぞれ $T_{\min }, T_{\max }$ と表わす. $T_{n}$ と $T_{n}{ }^{(N)}$ には式 (78) で表わされる関数が成立するから， $T_{n}$ が
最小および最大のとき， $T_{n}{ }^{(N)}$ も最小および最大にな り，そのときの $f_{j}{ }^{(s)}$ と $f_{j}$ の関係は式 (81) で表わさ れる.

$T_{n}{ }^{(N)}$ を最小にする $f_{j}$ は次のようになる.

$$
\left.\begin{array}{ll}
f_{j}=2^{j-1} & \left(j=1,2, \cdots, l_{1}\right) \\
f_{j}=2\left(n-d+l_{1}+1\right)-2^{l_{1}} & \left(j=l_{1}+1\right) \\
f_{2}=2 & \left(j=l_{1}+2, \cdots, d\right)
\end{array}\right\}
$$

ここに, $l_{1}\left(2 \leqq l_{1} \leqq d-1\right)$ は, 次の関倸を満足する整 数で, ソース数 $n$, 最大ソース高さ $d$ の河道網の最大 位数の取り得る最大值である.

$$
2^{l_{1}}-2 l_{1} \leqq 2(n-d)<2^{l_{1}+1}-2\left(l_{1}+1\right)
$$

式 (91) の $f_{j}$ に対する $f_{i}{ }^{(s)}$ の值を式 (81) より求め, それを式 (84) に代入して計算すれば,

$$
\begin{aligned}
T_{\min }= & -2^{l_{1}}+n\left(l_{1}+2\right) \\
& +\left(d-l_{1}-1\right)\left(d-l_{1}\right) / 2
\end{aligned}
$$

となる. 同様にして, $T_{n}$ の最大值 $T_{\max }$ は次のように 表わされる.

$$
\begin{aligned}
T_{\max }= & -2^{d-l_{2}+1}+n(d+1) \\
& -\left(l_{2}-2\right)\left(2 d-l_{2}+1\right) / 2
\end{aligned}
$$

ここに, $l_{2}\left(2 \leqq l_{2} \leqq d-1\right)$ は次の関係を満足する整数 である.

$$
\begin{array}{r}
2^{d-l_{2}+1}-2\left(d-l_{2}+1\right)<2(n-d) \\
\leqq 2^{d-l_{2}+2}-2\left(d-l_{2}+2\right)
\end{array}
$$

また, 式 (92) および (95) より， $l_{1}$ と $l_{2}$ との間には, 次の関係が成立する.

(1) $2^{l_{1}}-2 l_{1}<2(n-d)<2^{l_{1}+1}-2\left(l_{1}+1\right)$ のとき, $d-l_{2}+1=l_{1}$

このとき, 次の不等式が成立する.

$$
\begin{aligned}
-1 & +\frac{\left(l_{1}-2\right)\left(d-l_{1}\right)-l_{1}+2}{n}<d+l_{1} \\
- & \frac{T_{\min }+T_{\max }}{n}<1+\frac{\left(l_{1}-4\right)\left(d-l_{1}\right)-l_{1}}{n}
\end{aligned}
$$

(2) $2^{l_{1}}-2 l_{1}=2(n-d)$ のとき,

$$
d-l_{2}+2=l_{1}
$$

このとき, 次式が成り立つ.

$$
d+l_{1}-\frac{T_{\min }+T_{\max }}{n}=\frac{\left(d-l_{1}\right)\left(l_{1}-3\right)}{n}
$$

いま, $d$ として, 最大ソース高さの期待值 $d_{n}$ を考えれ ば, 式 (96) および (97) より, $n$ が大きい場合, 近似 的に次の関係が成立するものと思われる.

$$
d_{n} \simeq 2 e_{n}-u_{n} \cdots
$$

ここに, $u_{n}$ はソース数 $n$ の河道網の最大位数の期待值 である. 式 (90) を式 (98) に代入すれば, $d_{n}$ は次の ように表わされる。

$$
d_{n} \simeq 3.56 \sqrt{n-1}-u_{n}
$$


Table 5 には, 平均ソース高さの期待值 $e_{n}$ の 厳密解 (89) および近似解 (90), また, 最大ソ一 ス高さ $d_{n}$ の厳密解および近似解 (99) を示してい る. $d_{n}$ の厳密解は，反復関係を与える式を用い て, 数值計算によって, Shreve ${ }^{10)}$ が求めた值で ある. $n$ が大きくなるにつれて, 相対誤差が減少 しており, $n \geqq 3$ の範囲では, 期待値 $e_{n}, d_{n}$ は, 式（90）および（99）でおおよそ表わされること がわかる。

個々の河道網のトポロジー特性を表わす指標と して, ソース数 $n$, 最大位数 $k$ が与えられた場 合, この河道網の最大ソース高さ $d_{n}$ の理論値 は, 式 (99) より近似的に次のように表わされ る.

$$
d_{n} \simeq 3.56 \sqrt{n-1}-k
$$

この河道網の平均ソース高さ $e_{n}$ の理論值は, 式 (90) で与えられるものとする. 次に, ソース数 $n$, 最大位数 $k$ のこの河道網の平均ソース高さお よび最大ソース高さの実測值をそれぞれ $E_{n}, D_{n}$ で表わせば, この河道網のトポロジー的形状を示 す指標 $r_{e}, r_{d}$ を次のように定義することができる.

$$
\begin{aligned}
& r_{e}=100 \cdot\left(E_{n}-e_{n}\right) / e_{n} . \\
& r_{d}=100 \cdot\left(D_{n}-d_{n}\right) / d_{n}
\end{aligned}
$$

ここに， $e_{n}, d_{n}$ はそれぞれ式 (90) および (100) で与 えられる。

Table 6 に法, 10 河川対する平均ソース高さおよ び最大ソース高さの実測值と理論值，また， $r_{e}, r_{d}$ の 值をもあわせて示している. すべての河川に対して， $r_{e}, r_{d}$ の值は正であり,ランダム性の仮定より期待され る河川に比べてトポロジー的に細長くなっている. ラン ダム性の仮定 (I) は, 現在までに多くの研究者によ。 て検討され，ほぼ正しいことが確かめられている4)．10 河川に対する $r_{e}, r_{d}$ の值を検討する限り，日本の河川 は全般的に細長いことがわかる．次に，これらの河川に 対する $r_{e}, r_{d}$ の值を比較すると, 新宮川, 桂川および 揖斐川は，ほぼ平均的な河川であるのに対し，北山川， 大井川および愛知川はトポロジー的に細長くなっている ことがわかる. 特に, 大井川においてはその傾向は著し く, 大井川は地質, 地形的影響をかなり受けていること が予想される.これは, Table 4 の $G$ の值を比較した 結果と一致している.これらのことから, 河道網のトポ ロジー特性指標としては, $r_{e}, r_{d}$ の方が分岐比 $R_{b}$ に 比べて，その表わす情報量が多いことがわかる。これ は, 分岐比が単に河道の分岐状況のみを示すのに対し, 平均ソース高さおよび最大ソース高さは, 河道の分岐状 況ならびに河道の密集度 (compactness) をも示すから である.
Table 5 Expected mean source height $e_{n}$ and maximum source height $d_{n}$ of a channel network with $n$ sources

\begin{tabular}{|c|ccc|ccc|}
\hline$n$ & \multicolumn{3}{|c|}{$\begin{array}{c}\mathrm{e}_{n} \\
\text { approx. }\end{array}$} & error(\%) & \multicolumn{3}{|c|}{$\begin{array}{c}\mathrm{d}_{n} \\
\text { strict }\end{array}$} & strict & approx. & error(\%) \\
\hline 1 & 1.00 & 0.00 & 100.0 & 1.00 & -1.00 & 200.0 \\
2 & 2.00 & 1.78 & 11.0 & 2.00 & 1.56 & 22.0 \\
3 & 2.67 & 2.53 & 5.2 & 3.00 & 3.05 & 1.7 \\
4 & 3.20 & 3.08 & 3.8 & 3.80 & 3.97 & 4.5 \\
5 & 3.66 & 3.56 & 2.7 & 4.57 & 4.69 & 2.6 \\
6 & 4.06 & 3.98 & 2.0 & 5.24 & 5.34 & 1.9 \\
7 & 4.43 & 4.36 & 1.6 & 5.88 & 5.96 & 1.4 \\
8 & 4.77 & 4.71 & 1.3 & 6.47 & 6.57 & 7.5 \\
9 & 5.09 & 5.04 & 1.0 & 7.03 & 7.15 & 1.7 \\
10 & 5.39 & 5.34 & 0.9 & 7.56 & 7.71 & 2.0 \\
20 & 7.78 & 7.76 & 0.3 & 11.92 & 12.08 & 1.3 \\
50 & 12.44 & 12.46 & 0.2 & 20.73 & 20.83 & 0.5 \\
100 & 17.66 & 17.71 & 0.3 & 30.80 & 30.78 & 0.1 \\
200 & 25.02 & 25.11 & 0.4 & 45.12 & 45.13 & 0.0 \\
500 & 39.60 & 39.76 & 0.4 & 73.87 & 73.71 & 0.2 \\
\hline
\end{tabular}

Table 6 Observed and calculated mean source height $\bar{e}_{n}$ and maximum source height $\bar{d}_{n}$

\begin{tabular}{|c|ccc|ccc|}
\hline River & \multicolumn{3}{|c|}{$\overline{\mathrm{e}}_{\mathrm{n}}$} & \multicolumn{3}{c|}{$\overline{\bar{d}}_{\mathrm{n}}$} \\
& Obs. & Calc. & $\mathrm{r}_{\mathrm{e}}$ & Obs. & Calc. & $r_{\mathrm{d}}$ \\
\hline Shingu & 48.7 & 43.8 & 9.8 & 89 & 81.6 & 9.0 \\
Tozu & 33.3 & 28.1 & 18.2 & 65 & 51.3 & 26.7 \\
Kitayama & 40.0 & 27.7 & 44.4 & 62 & 50.4 & 23.1 \\
Kizu & 45.3 & 34.2 & 32.8 & 66 & 62.3 & 6.0 \\
Katsura & 33.2 & 30.4 & 9.1 & 64 & 55.8 & 14.6 \\
Oi & 43.3 & 26.5 & 63.3 & 85 & 48.0 & 76.9 \\
Ibi & 19.0 & 18.7 & 2.0 & 37 & 32.3 & 14.4 \\
Ado & 23.0 & 17.3 & 33.5 & 36 & 29.5 & 22.0 \\
Yasu & 18.8 & 14.9 & 26.2 & 31 & 25.8 & 20.2 \\
Echi & 14.5 & 10.8 & 33.7 & 23 & 17.7 & 30.3 \\
\hline
\end{tabular}

次に, 各流域内におけるトポロジ一特性の変化につい て調べてみよう.ソース数 $n$, 最大位数 $k$ の河道網にお けるマグニチュード $i$ のリンクより上流の小河道網に対 する平均ソ一ス高さおよび最大ソース高さの平均值をそ れぞれ， $\bar{e}_{i}, \bar{d}_{i}$ で表わせば， $\bar{e}_{i}$ は式 (90) より近似的に 次のようになる.

$$
\left.\begin{array}{rlrl}
\bar{e}_{i} & =1 & & (i=1) \\
& =2 & & (i=2) \\
& =1.78 \sqrt{i-1} & & (3 \leqq i \leqq n)
\end{array}\right\}
$$

$\bar{d}_{i}$ は，式 (99) の $u_{n}$ の代りに式 (34) で与えられる 河道リンク位数の平均值 $\bar{u}_{l}$ を用い，同様に次のように 表わせる.

$$
\begin{aligned}
& \bar{d}_{i}=1 \quad(i=1) \\
& =2 \quad(i=2) \\
& =3.56 \sqrt{i-1}-\left(1+\log i / \log R_{b}\right) \\
& (3 \leqq i \leqq n))
\end{aligned}
$$

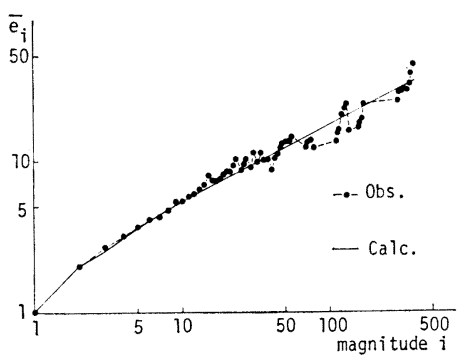

Fig. 6 Observed and calculated average mean source height $\bar{e}_{i}$ versus magnitude $i$ for Kizu River. 


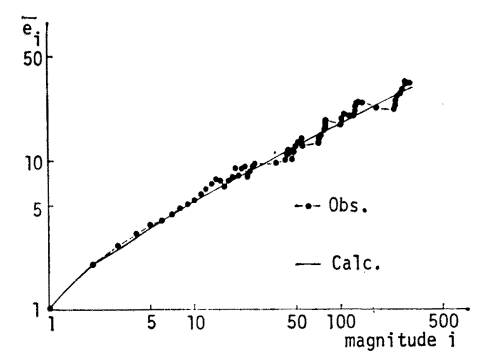

Fig. 7 Observed and calculated average mean source height $\bar{e}_{i}$ versus magnitude $i$ for Katsura River.

Fig. 6 には木津川, また, Fig. 7 には桂川の平均ソ 一ス高さ $\bar{e}_{i}$ の実測值と理論值を示している. 桂川流域 は，ほぼ秩父古生層よりなる地質構造の一様な流域であ る. そのためか, 理論值と実測值の適合性もよい.木津 川流域は，マグニチュード 129 の伊賀川と 160 の名張 川とが合流してできる流域である.そのため，マグニチ ユードが 100 以上では実測值の変動が大きい.すなわ ち, 木津川流域内の詳しいトポロジー特性を知るために は, 流域を伊賀川流域, 名張川流域および合流点より下 流域との 3 流域に区分して取り扱うのが適当と思われ る.

Fig. 8 亿野洲川，また, Fig. 9 亿愛知川の最大ソー ス高さ $\bar{d}_{i}$ の実測值と理論值とを示している. ソース数 の大きい木津川および桂川に比べて, 実測值と理論值と の適合性は悪い，また，これら 4 河川流域に対する実測

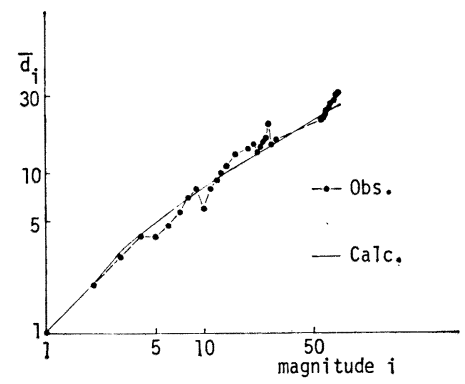

Fig. 8 Observed and calculated average maximum source height $\bar{d}_{i}$ versus magnitude $i$ for Yasu River.

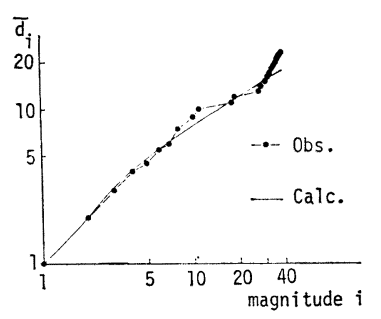

Fig. 9 Observed and calculated average maximum source height $\bar{d}_{i}$ versus magnitude $i$ for Echi River.
值からわかるように, 最下流域では, マグニチュードの 非常に小さい支川が連続的に合流して抢り，そのため流 域全体としては，平均的な河川よりトポロジー的に細長 くなっていることがわかる.

\section{6. 結 語}

本研究は, 河道網構成最小単位であるリンクおよび節 点に対して定義されるマグニチュード括よび高さの概念 を基礎とし，トポロジー的ランダム性の仮定より得られ る河道網のトポロジー特性量に関する統計則ならびに指 標を展開したものである. 同時に, 従来より提案されて いる河道網の階層的構造を表現する河道分類法の相互関 係を明らかにした，その結果，本論文で提案した河道り ンク位数に対しても位数理論の地形則が成立することが 証明された. 現在のところ，位数が広く用いられてお り,その欠点を補う意味で, 河道リンク位数は重要であ ると考えられる.

対象流域のトポロジー特性を示寸指標として, ソース 数, 最大位数を与えれば, この河道網の 分岐比は決ま り,また，この流域内の任意のリンクあるいはそのリン クより上流の小河道網に対して定義されるリンク数, 河 道リンク位数, 平均ソース高さおよび最大ソース高さ は, そのリンクのマグニチュードの関数としてほぼ表わ されることがわかった. 個々の河道網の地質, 地形的影 響の程度，また，トポロジ一的形状を定量的に比較する には，指標 $G, r_{e}$ および $r_{d}$ の值を検討することによ り, 従来の分岐比の比較より詳しい情報が得られること もわかった.この指標をわが国の全河川に対して実測, 比較すれば, トポロジー的特徴によって, 河川のもつ性 格を定量的に分類することも可能となろう．

最後に，本研究をすすめるにあたり，種々の資料の分 類, 整理に協力された棚橋通雄 (建設省), 吉田八左右 (京都大学大学院学生) の両君に感謝の意を表わす次第 であります.

\section{参 考 文 献}

1) Horton, R.E. : Erosional development of streams and their drainage basins : Hydrophysical approach to quantitative morphology, Geol. Soc. Amer., Bull. $56,1945$.

2) Shreve, R.L. : Statistical law of stream numbers, J. Geol. $74(1), 1966$.

3) Jarvis, R.S. : New measure of the topologic structure of dendritic drainage networks, W.R.R. Vol. 8, No. 5, 1972.

4) Smart, J.S. : Channel networks, Advan. Hydrosci., 8, 1972.

5) Ishihara, T., Y. Iwasa and T. Takasao: Stochastic study of channel distribution in river basins, Proc. Int. Hydrol. Symp., Fort Collins, Colo. Vol. 1, 1967.

6) Scheidegger, A.E. : The algebra of stream order 
numbers, U.S. Geol. Surv. Profess. Paper 525 B, 1965.

7) Stall, J.B. and Y.S. Fok : Hydraulic geometry of Illinois streams, Uni. of Illinois W.R.C. Res. Report, No. 15, 1968.

8) Woldenberg, M.J. : Horton's laws justified in terms of allometric growth and steady state in open systems, Bull. Geol. Soc. Amer., Vol. 77, 1966.

9) Werner, C. and J.S. Smart : Some new methods of topologic classification of channel networks, Geogr. Anal., 5, 1973.

10) Shreve R.L. : Variation of mainstream length with basin area in river networks, W.R.R. Vol. 10, No. 6, 1974 .

11）藤田睦博：流域地形構造とその統計測に関する基礎的研 究, 土木学会論文報告集, 第 234 号, 1975.

12）小林信久：ダム群による水配分システムの研究, 京都大 学卒業論文, 1974.

13）高棹珴馬: 水工水理学, 丸善, pp. 363 365, 1972.

14）岩佐義朗・小林信久・棚橋通雄 : 河道ネットワークに関 する基礎的研究, 土木学会年次講演会集, 1975 .

15）小林信久: 流域の地形形態に関する河川工学的研究, 京 都大学大学院修士論文, 1976 .

(1976.6.9.受付) 